\title{
Industrial Sector Output and Its Relationship with Government Expenditure, Credit, and Foreign Aid in Nepal
}

\author{
Arjun Kumar Dahal* \& Bijayahari Khatiwada** \\ *Mechi Multiple Campus, Bhadrapur, Jhapa, Nepal \\ **Mahendra Morang Adarsh Multiple Campus, Biratnagar, Nepal \\ *Email: arjun.dahal@memc.tu.edu.np \\ ORCID id: https://orcid.org/0000-0003-4816-4576 \\ **Email: bijayhari@gmail.com
}

\begin{abstract}
The study's goal is to look into the state, long-run relationship, and casual link of government spending, commercial bank lending, and foreign aid to Nepal's industrial sector output. The research design for this study is descriptive and analytical. The secondary data are processed using Excel and EViews10 software from 1989/90 to 2018/19. The Johnsen Co-integration test and Granger Causality test describe and analyze the relation and causal impact of variables. The credit of commercial banks highly influences industrial output. The industrial sector output, government expenditure, loans, and foreign aid were Co-integrated or had long-run association ship. This paper contributes to the policy debate on whether government expenditure and foreign support to the industrial sector are justified or not. The author is unaware of another study, finding, and location related to industrial output and its affecting factors like government expenditure, loans, and foreign aid.
\end{abstract}

Keywords: Industrial sector, credit, foreign aid, government expenditure, causal relation.

JEL Classification:E20, E23, E27

\section{How to Cite}

Dahal, A. K., \& Khatiwada, B. (2021). Industrial sector output and its relationship with government expenditure, credit, and foreign aid in Nepal. International Journal of Business, Management \& Economics, 2(2). 134-148. DOI: https://doi.org/10.47747/ijbme.v2i2.306

\section{Introduction}

Industrial development is necessary for the modernization of agriculture, development of science and technology, promotion of trade, alleviation of poverty and employment, high standard of living, social changes, and urbanization. The development of the industrial sector ensures the 
economic development of the nation. Industrial development generates long-term economic growth that can revolutionize a country's economy. Industrial and economic growth are inextricably linked. Industrialization creates jobs, expands educational possibilities, promotes growth and innovation, and makes better use of resources. Industrial development is the process of establishing and expanding industries within a given economy. Mass manufacturing, technological advancements, and other services are among these industries.

Nepal has a brief history of industrialization. After the Nepal Companies Act was enacted in 1936, the Biratnagar Jute Mills became the country's first joint-venture company. In the 1950s and 1960s, a few additional government-owned industries were established, typically with the assistance of China and the then-USSR. (Jha, 2016). However, expansion in the manufacturing sector, both in size and productivity, can aid Nepal in alleviating poverty, generating gainful employment, and accelerate economic prosperity as it has done in the other newly developing countries. (Aryal, et al., 2014).

Industrialization is vital for an economy to become middle class and prosperous. The industrial sector output contributes nearly 16\% of the total GDP of Nepal (K.C, 2019Tightening domestic credit conditions, higher foreign direct investment thresholds, and sustained low execution rates of public investment projects led in a reduction of investment and new firm registrations in the manufacturing sector. (WB., 2020). The industrialization rate in Nepal is very slow. Industrial development is highly affected by the political condition and stability of the government. The industrial sector output depends on commercial bank's credit, government expenditure, and foreign aid to the industrial sector. In a free-market economy, the involvement of the government looks pretty nominal. The government expenditure on the industrial sector goes to regular expenditure and government enterprises. Therefore, the government expenditure of the industrial sector seems less unproductive. Even in some developing countries, it hurts the overall industrial output of the nation. Like other developing countries, the government of Nepal allocates less amount to the industrial sector.

The credit of commercial banks is just like the lifeblood for the industrial sector's development. It fulfills the gap of deficiency of capital and needed investment in this sector. The industrial sector output depends upon the individual behavior of entrepreneurs and commercial banks' loan disbursement policies. The financial services of commercial banks stimulate to determine the industrial output. The industrial sector of Nepal is highly picking because of the tough competition with foreign products, even in the domestic market. The credit of commercial banks has a positive impact on the increase in the industrial sector output. There are 161 banking and financial institutions assisting Nepal's industrial sector, including 27 commercial banks, 23 development banks, 22 financing businesses, and 89 microfinance firms. (NPC, 2019). The cooperatives and co-operative societies are also providing funds to the industrial sector.

Nepal receipts foreign aid in the form of loans and grants every year. USAID, ADB, JICA, SAC, IFAD, and World Bank are the primary development partners of Nepal. However, the grants and loans from foreign countries especially go to the social and industrial sectors. Foreign aid to the industrial sector comes to Nepal for liberalizing Reform in these areas (Jac \& Stephen, 2015). Foreign aid especially goes to the exploration of mines, surveys, pieces of training to the 
ministry of industries, policy formation, and the improvement of public enterprises, but not to the direct investment and stimulation to the industrial sector. So, the role of foreign aid may not show a positive impact on the increase in the industrial sector output in developing countries like Nepal. In general, the government expenditure, loan of commercial banks and foreign aid positively impacts the industrial sector. Still, this impact is conditional on an excellent institutional and policy environment of the nation.

Industrial development is essential for rapid economic growth and employment generation. The government expenditure, commercial banks' credit, and foreign aid influenced the size of the industrial sector's output. Government expenditure and foreign aid are nullified to increase the industrial sector output in the free-market economy. Failure to measure the productivity of industrial sector output, whether from government expenditure or credit, or foreign aid, is a severe problem of the industrial sector. Various research covers the relation and impact of government expenditure and Commercial banks credit to industrial development. The role and relation of foreign aid to industrial sector output are unidentified. To fill such a gap, this research has significant value. In this study, the following research objectives are designed:

1. To show the condition of industrial sector output, government expenditure, loans, and foreign aid.

2. To examine the causal relationship among the variables like industrial sector output, government expenditure, credit, and foreign aid.

3. To identify the impact of credit of commercial banks, government expenditure, and foreign aid on the industrial sector output of Nepal.

The remaining portion of the article is structured as follows: The current literature is summarised in Section 2. Section 3 is concerned with the general research strategy; Section 4 is concerned with the empirical findings, and Section 5 is concerned with the study's conclusion and consequences.

\section{Literature Review}

Some related kinds of literature are reviewed in this section:

Lorember \& Emmanuel (2016) looked studied the impact of commercial bank lending on Nigeria's manufacturing sector production from 1980 to 2015. They utilized five variables: manufacturing sector output, inflation rate, interest rate, loans and advances, and broad money supply. The study found that the inflation rate and interest rate hurt manufacturing sector output. At the same time, loans and advances and a broad money supply positively affect the manufacturing sector output in Nigeria. Between 1975 and 2009, Tawose (2012) analyses the impact of bank loans and advances on industrial performance in Nigeria. The analysis was carried out using the Co-integration and Error Correction method. The findings revealed that all of the selected explanatory factors were co-integrated with industrial performance. Real GDP was used as a proxy for the industrial sector as a dependent variable. At the same time, the independent variables were Commercial Banks' Loans and Advances to the Industrial Sector (BLM), Aggregate Saving (SAV), Interest Rate (INT), and Inflation Rate (INF). This implies

Published by:

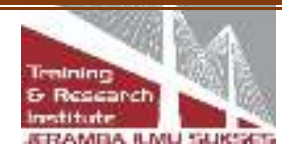


that the commercial banks' loans and advances to the industrial sector, collective saving, interest rate, and inflation rate all play a role in explaining the real Gross Domestic Product behavior of the Nigerian industrial sector. Ogar Nkamaro et al. (2014) observed how commercial bank credit could influence the manufacturing sector in Nigeria. If well channeled to worthy customers or sectors, the study shows that commercial bank credit will enhance economic growth. The finding revealed that commercial bank credit had a significant relationship with the manufacturing sector. It was recommended that the government endeavor to ensure that there are available and sufficient credit allocated to the manufacturing sector with reasonable or affordable interest rates. Muchingami, Monametsi \& Paradza (2017) observed bank lending as a stimulating factor for economic growth. The study strived to examine the impact of bank lending on manufacturing sector performance in Zimbabwe from 2009-2015 by using an ordinary least squares (OLS) regression model. The link between the dependent and independent variables was established using the ordinary least square multiple regression model. The study discovered that commercial bank loans and the amount of the manufacturing index had a favorable connection. Adetiloye, Olokoyo, and Taiwo (2016) focused their research on the role of bank loans in emerging nations' industrialization. The empirical link between bank loans and industrial production was investigated in Johnsen's Co-integration text. The findings indicated an inelastic link between bank lending and the production of the industrial sector, and hence the growth of industrialization. This study concluded that banks are important catalysts for industrialization.

Hacievliyagil and Eksi (2017) investigated the link between bank loans and performance, as well as the expansion of manufacturing sub-sectors. As a dependent variable, the Industrial Production Index was employed uniquely. The results of the ARDL bound co-integration test support the notion that bank credits are more effective than loan rates in the industrial sector. Furthermore, except for machinery, an increase in bank credit leads to an increase in industrial production in all sub-sectors. In terms of the relevance of bank loans for industrial production, there are various degrees of causality. On the other hand, causality links may be found at various levels in all sub-sectors except machinery and chemical sub-sectors, starting with loan interest rates. As a result, this study concludes with data supporting the supply leading hypothesis, namely that the financial sector leads and generates economic growth.

Lintel, et.al. (2014) discovered that (i) bankers' efforts and productivity have significantly improved in Nepal, (ii) bankers' efforts significantly explain the banking sector's productivity, (iii) the proportion of nonperforming loans has significantly decreased, and (iv) banking services have become more expensive, despite a moderate decline in the bank spread. Their approach is different from the widely used data envelopment analysis (DEA) of bank productivity, hence complements the literature. Ehikioya, Ehikioya, et al. (2013) looked at the relationship between commercial bank loan availability and sectoral production performance in the Nigerian economy between 1986 and 2010. To determine the connection between various commercial bank credits and sectoral output growth, the growth model was calculated using Ordinary Least Square (OLS) approaches. The variables were checked for stationarity, and the Augmented Dickey-Fuller test was used to do co-integration analysis. An error correction test was also carried out. The study discovered that a long-run link exists between commercial bank loan supply and sectoral

Published by:

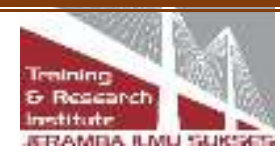


production performance. The research also indicates that commercial bank credit has a direct and indirect impact on the economy. Nonetheless, the preceding period's credit supply and demand have a direct and considerable influence on agricultural, industrial, and service sector production. This evidence backs up the a priori hypothesis.

In Nigeria, Falade and Olgbaju (2015) looked at the link between government spending and manufacturing production. The stationarity of the variables of interest at their initial difference was established by econometric evidence. At the same time, at a 5\% level of significance, the Johansen co-integration method reveals the presence of one co-integrating connection. Also, whereas government capital spending has a positive connection with manufacturing sector production in Nigeria, recurrent expenditure has a negative link with manufacturing sector output, according to error correction estimates. According to the findings, a $1 \%$ increase in government capital spending improved manufacturing sector production by 11.2 percent, but recurrent expenditure decreased by $26.9 \%$. This demonstrates that government capital spending has a beneficial influence on manufacturing production. Anyeneh, Ezu, and Ananwade (2019) calculated the long-run and short-run dynamics of government expenditure and industrial growth in Nigeria from 1981 to 2016, intending to determine how government expenditure has affected the industrial sector. The method used was Autoregressive Distributed Lag (ARDL). Despite the steady growth in government expenditure and numerous government initiatives aimed at enhancing industrial performance, they discovered that government spending has had no longterm or short-term positive impact on Nigerian industrial development.

The impact of capital and recurrent government spending on the industrial sector was studied by Emmanuel and Oladiran (2015). At a 5\% level of significance, econometric evidence from the Johnsen Co-integration test indicated the existence of one co-integrating link. Capital spending has a positive relationship with industrial production, whereas recurring expenditure has a negative relationship. Iweriebor, Egharevaba, and Adegboye (2015) investigated the impact of government expenditure on the Nigerian industrial sector in a dynamic framework. In the near run, public expenditure has little influence on industrial productivity, according to the study. Furthermore, even in the long run, government expenditure has a relatively small impact on industrial production, implying a mismatch between government spending and the actual economy.

All of the studies in Nepal are based on government spending or commercial bank lending to the industrial sector. The majority of research look at the state, relationship, and effects of government spending and commercial bank lending on industrial output. Nevertheless, this study emphasizes finding out the combined effect of government expenditure, commercial banks' profit, and foreign aid on the industrial output of Nepal.

\section{Materials and Methods \\ 3.1 Research design}

This study is based on descriptive as well as analytical research design. Some econometric and statistical tools have been applied to show the relation and impact of government expenditure,

Published by:

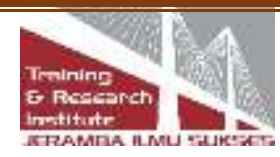


loans, and foreign aid on industrial output. Excel Minitab 19 and EViews10 software packages are used for analysis, interpretation, and explore the result.

\subsection{Data and Data Analysing Tools}

In this study, the time series secondary data are collected from various Nepal's economic surveys, Central Bureau Statistics (CBS), and various publications of the ministry of finance and the central bank of Nepal. The data covers 30 years from the fiscal year 1989/90 to 2018/19. The Johnsen Co-integration test, Granger causality test, Vector Autoregressive model, etc., have been used to test whether these variables have a long-run association, whether on variable Granger cause another variable or not, whether one independent variable is significant to explain the dependent variable or not.

\subsection{Model Specification}

The industrial sector's gross output is affected by government expenditure, commercial banks' credit, and foreign aid given to the industrial sector. Here, Industrial output is a dependent variable, and government expenditure, credit of commercial banks, and foreign aid are independent variables. The following regression equation is formed to be conformed about the null hypothesis of saying there is no impact of government expenditure, loans, and foreign aid to the industrial output of Nepal.

ISGO $=\mathrm{f}($ ISGE, ISLNC, ISFAID, )

ISO, ISGE, ISLNC, and ISFAID represent the industrial sector's output, government expenditure, credit, and foreign aid. There may be other affecting factors of industrial output.

\subsection{Co-integration and causality test}

In the data analyzing tool process, the Johnsen co-integration test and Granger Causality test have been used. The Johnsen Co-integration Test is used to check the co-integration among the concerned variables. In this model, the co-integration relation is presented in the following equation.

$$
Y t=\beta X_{t}+\varepsilon_{t}
$$

$\mathrm{H}_{0}: \beta=0$ (series are not co-integrated). $\quad \mathrm{H}_{\mathrm{A}}: \beta \neq 0$ (series are co-integrated)

When Null hypothesis $\mathrm{H}_{0}$ : is rejected, the variables are co-integrated and take joint action in the long run. Both Trace and Max-eigenvalue tests have been used to test the long-run association of the variables. The Johnsen Co- integration test cannot show the change of direction of variables. To show the direction of change of all pairs of variables, the Granger Causality Test is used. For the Granger Causality Test, we have to estimate the Vector Autoregression (VAR) model as given below. In this model, all variables are initially considered systematically and endogenously (Rahman, Rahman, et al. 2011)

$$
Y_{t}=a_{0}+a_{1} Y_{t-1}+\cdots+a_{p} Y_{t-p}+b_{1} X_{t-1}+\cdots+b_{p} X_{t-p+\ldots \ldots .}+\mu_{\mathrm{t}}
$$

Published by:

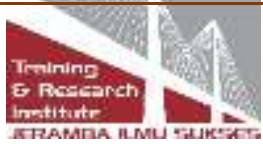

Page 139 


$$
X_{t}=c_{0}+c_{1} X_{t-1}+\cdots+c_{p} X_{t-p}+d_{1} Y_{t-1}+\cdots+d_{\mathrm{p}} Y_{t-\mathrm{p}+\ldots . .}+v_{t}
$$

In the notation of the above-augmented regression, $p$ is the longest lag length for which the lagged value of $y$ is significant. Testing null hypothesis $\mathrm{H} 0: \mathrm{b}_{1}=\mathrm{b}_{2}=\ldots=\mathrm{b}_{\mathrm{p}}=0$ against alternative hypothesis $\mathrm{H}_{\text {.A. }}$ : When the null hypothesis is not rejected, $\mathrm{X}$ does not Granger cause $\mathrm{Y}$. Similarly, testing null hypothesis $\mathrm{H}_{0:} \mathrm{d}_{1}=\mathrm{d}_{2}=\ldots=\mathrm{d}_{\mathrm{p}}$ against alternative hypothesis $\mathrm{H}_{\text {.A. }}$ : When the null hypothesis is not rejected $\mathrm{Y}$ does not Granger cause $\mathrm{X}$ variable. In all cases, the null hypothesis must be rejected for their granger causality between variables.

\section{Result and Discussion}

4.1 Condition of Industrial Sector GDP Government Expenditure, Loan, and Foreign Aid.

Industrial output is the function of government expenditure, credit, foreign aid, and other factors. Normally, the gross output of the industrial sector and loan disbursement bt C.B.s was found to increase trend year by year in the study period from 1989/90 to 2018/19. However, the government expenditure and foreign aid to the industrial sector were found more fluctuating. The condition of Industrial sector output, government expenditure, loans, and foreign aid is presented in Annex I. The following table 1 shows the descriptive statistical measurement.

Table 1: Descriptive statistical calculation of Variables

\begin{tabular}{lllll}
\hline Descriptions & ISGO & ISGE & ISLNC & ISFAID \\
\hline Mean & 36215.83 & 739.3473 & 647963.8 & 312.3070 \\
Median & 39749.50 & 646.8850 & 52636.70 & 158.2200 \\
Maximum & 60809.00 & 2448.200 & 5689621. & 2174.300 \\
Minimum & 6455.000 & 167.8000 & 3134.700 & 0.050000 \\
Std. Dev. & 14189.99 & 450.8861 & 1607666. & 450.5243 \\
Skewness & -0.496015 & 2.164302 & 2.570946 & 2.904934 \\
Kurtosis & 2.440843 & 8.588372 & 7.840878 & 11.66149 \\
Jarque-Bera & 1.620973 & 62.45839 & 62.34145 & 135.9699 \\
Probability & 0.444642 & 0.000000 & 0.000000 & 0.000000 \\
Sum & 1086475. & 22180.42 & 19438914 & 9369.210 \\
Sum Sq. Dev. & $5.84 \mathrm{E}+09$ & 5895650. & $7.50 \mathrm{E}+13$ & 5886193. \\
Coeff. of Variation & $39.18 \%$ & $60.08 \%$ & $248.1 \%$ & $144.26 \%$ \\
\hline
\end{tabular}

Source: - Author's Calculation by using Minitab 19

Source of main data: - Economic Surveys of Nepal Fiscal year 2001/2002(GoN, 2002). 2008/09 (GoN, 2009) and 2019/20 (GoN 2020)

Where ISGO= Industrial sector gross output.

ISGE = Industrial sector expenditure of government

ISLNC= Industrial sector loan of commercial banks

ISFAID = Industrial sector foreign aid

Published by:

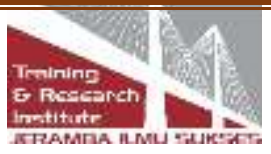


According to Table 1, the industrial sector output ranges from 6455 to 60809 million rupees during 30 years from 1989/90 to 2018/19. Similarly, the government expenditure, loan of CBS, and foreign aid to the industrial sector ranges from 167.8 to 2448.2, 3134.7 to 5689621 , and 0.05 to 2174.3 million rupees, respectively. The coefficient of Variation (CV) of industrial sector output, government expenditure, loan, and foreign aid were found 39.18\%, 60.98\%, 248.1\%, and $144.26 \%$, respectively. The CV of industrial sector output was smaller than other variables, so industrial sector output is more consistent or stable than other variables during the study period. Likewise, the CV of the industrial sector loan of C.B.s was highest $(248.1 \%)$ than other variables. So, the credit disbursement of C.B.s to the industrial sector was found more variable or unstable than others. The second position variability is taken by foreign aid, and industrial sector government expenditure stands in the second position in case of stability. The standard deviation tells how to spread out a variable is around the mean. The Jarque-Bera statistics is a test of normality. Lower the value of Jarque-Bera statistics indicates the more regular distribution of the data.

\subsection{Measurement of Causal Relationship}

\subsubsection{Lag selection and unit root testing}

Lag selection is made for the identification of affecting times between the variables. The lag difference must be recognized for the system equations like the Johnsen Co-integration test and vector Autoregression model. Annex II shows the condition of L.R., FPE, AIC, SC, and H.Q. values. Based on AIC criteria, the lower the AIC value better the model. At lag one, the AIC value is minimum. However, in this model, all criteria suggest selecting lag 1 to estimate the system equation model. Recall that the sign asterisk (*) suggests selecting the lag of the variables.

Unit root testing is used to decide the condition of stationary or non-stationary data. To check the stationary of data, the Augmented Dickey-Fuller (ADF) test is used. The result of the ADF test is presented in Annex III. All the variables are non-stationary in level form. Most of the variables are found stationary at first difference because the $\mathrm{P}$-value is less than or equals to $0.05(\mathrm{P} \leq 0.05)$ or the absolute ADF test value is greater than the absolute critical value at a $5 \%$ level of significance. At first difference, data can be used in different types of econometric models.

\subsubsection{Johnsen co-integration and Granger Causality Test}

1) Johnsen Co-integration Test

The data of four variables like industrial sector gross output, government expenditure, commercial banks' credit (CBS), and foreign aid are found stationary at first. Therefore, we can operate the Johnsen Co-integration Test. It checks that the variables have a long-run association or not. The outcomes of the Johnsen Co-integration Test are listed in table 2

Table 2: Johnsen Co-integration Test

Sample (adjusted): 19892018

Included observations: 28 after adjustments

Published by:

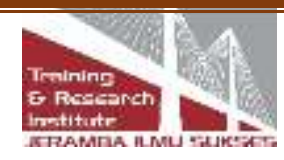


Trend assumption: Linear deterministic trend

Series: LISGO LISGE LISLNC LISFAID

Lags interval (in first differences): 1 to 1

\begin{tabular}{lclll}
\hline \multicolumn{4}{l}{ Unrestricted Cointegration Rank Test (Trace) } \\
\hline Hypothesized & & Trace & 0.05 & \\
\hline No. of CE(s) & Eigenvalue & Statistic & Critical Value & Prob.** \\
None $*$ & 0.788799 & 71.69938 & 47.85613 & 0.0001 \\
At most 1 & 0.468593 & 28.16089 & 29.79707 & 0.0763 \\
At most 2 & 0.309893 & 10.45854 & 15.49471 & 0.2471 \\
At most 3 & 0.002607 & 0.073088 & 3.841466 & 0.7869 \\
\hline
\end{tabular}

Trace test indicates one co-integrating equation at the 0.05 level

$*$ denotes rejection of the hypothesis at the 0.05 level

**MacKinnon-Haug-Michelis (1999) p-values

Unrestricted Cointegration Rank Test (Maximum Eigenvalue)

\begin{tabular}{lcclc}
\hline $\begin{array}{l}\text { Hypothesized } \\
\text { No. of CE(s) }\end{array}$ & Eigenvalue & $\begin{array}{l}\text { Max-Eigen } \\
\text { Statistic }\end{array}$ & $\begin{array}{l}0.05 \\
\text { Critical Value }\end{array}$ & Prob.** \\
\hline None ${ }^{*}$ & 0.788799 & 43.53849 & 27.58434 & 0.0002 \\
At most 1 & 0.468593 & 17.70235 & 21.13162 & 0.1414 \\
At most 2 & 0.309893 & 10.38545 & 14.26460 & 0.1878 \\
At most 3 & 0.002607 & 0.073088 & 3.841466 & 0.7869
\end{tabular}

Source: - Author's Calculation by using EViews10

The Max-eigenvalue Test indicates one co-integrating equation at the 0.05 level

$*$ denotes rejection of the hypothesis at the 0.05 level

**MacKinnon-Haug-Michelis (1999) p-values

Where LISGO= Industrial sector gross output (taking log)

LISGE = Industrial sector expenditure of government (taking log)

LISLNC $=$ Industrial sector loan of commercial banks (taking log)

LISFAID= Industrial sector foreign aid (taking log)

The outcomes of the Johnsen Co-integration Test, listed in table 1, show the condition of longrun association among the variables. Both trace and Max-Eigen test statistics indicate the longrun relationship among the industrial sector gross output, Credit of $\mathrm{CBs}$, and foreign aid to the industrial sector of Nepal. In the trace method, the P-value is 0.0001, which is less than 0.05. That means equations are co-integrated. So, we can reject the null hypothesis of saying there are no co-integrated equations. The same conclusion can be drawn from the Maximum Eigenvalue test at a $5 \%$ level of significance.

2) Granger Causality Test

Published by:

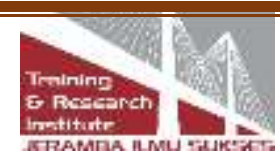


The Granger Causality Test checks the causal relationship between two variables in the timerelated data. It establishes the causal relationship between a pair of variables used in the study, but we have to emphasize the pairs desired to explain in the study. The following Table 2 represents the pairwise outcome of the Granger Causality Test.

Table 3: Outcomes of the Granger Causality Test

Pairwise Granger Causality Tests

Sample: 19892018

Lags: 1

\begin{tabular}{llcl}
\hline Null Hypothesis: & Observations & F-Statistic & Prob. \\
\hline LISGE does not Granger Cause LISGO & 29 & 0.34197 & 0.5637 \\
LEGO does not Granger Cause LISGE & & 1.47665 & 0.2352 \\
\hline LLC does not Granger Cause LISGO & 29 & 8.17033 & 0.0083 \\
LEGO does not Granger Cause LISLNC & & 0.79895 & 0.3796 \\
\hline LISFAID does not Granger Cause LISGO & 29 & 0.58751 & 0.4503 \\
LISGO does not Granger Cause LISFAID & & 3.01992 & 0.0941 \\
\hline LLC does not Granger Cause LISGE & 29 & 0.01640 & 0.8991 \\
LISGE does not Granger Cause LISLNC & & 0.19953 & 0.6588 \\
\hline LISFAID does not Granger Cause LISGE & 29 & 0.13361 & 0.7177 \\
LISGE does not Granger Cause LISFAID & & 2.24673 & 0.1459 \\
\hline LISFAID does not Granger Cause LISLNC & 29 & 0.00672 & 0.9353 \\
LISLNC does not Granger Cause LISFAID & & 0.54739 & 0.4660 \\
\hline
\end{tabular}

Source: - Author's Calculation by using EViews 10

Where LISGO= Industrial sector gross output (taking log)

LISGE= Industrial sector expenditure of government (taking log)

LISLNC $=$ Industrial sector loan of commercial banks (taking log)

LISFAID = Industrial sector foreign aid (taking $\log$ )

According to Table 3, only the Credit of $\mathrm{CBs}$ on the industrial sector does granger cause to industrial sector output of Nepal. The P-value is 0.0083 of saying industrial sector credit (ISLNC) does not Granger cause industrial sector gross output. It is less than 0.05 . So, we can reject the null hypothesis. It means ISLNC does Granger cause ISO. Other pairs of variables do not Granger cause each other. Normally, in a market economy, the industrial sector output depends upon private investment and enterprises. The government expenditure on the industrial sector is very nominal and especially goes to the public enterprises and regular expenditure of ministry and departments. The public enterprises are tiny in quantity, and their economic

Published by:

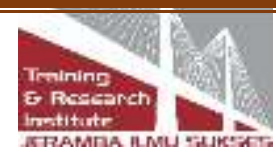


preferences are not satisfactory. So industrial sector government expenditure and foreign aid do not have granger cause to industrial sector gross output.

\section{Conclusions, policy implications, and limitations}

The industrial sector is affected by the volume of government expenditure, loans of C.B.s, and foreign aid to the industrial sector. The government expenditure and foreign aid to the industrial sector are found more fluctuating. The industrial sector output is found more stable, and the commercial bank's credit to the industrial sector is more unstable than other variables. The industrial sector output, government expenditure, commercial banks credit, and foreign aid are co-integrated or have long-run association ships. The industrial sector credit of C.B.s does granger cause to industrial sector output of Nepal. Industrial sector government expenditure and foreign aid do not each have granger cause on the industrial sector output of Nepal.

The industrial sector government expenditure and foreign aid are not beneficial to increasing Nepal's industrial sector output. The industrial sector government expenditure, credit, and foreign aid jointly affect the industrial output, and Credit of CBs separately can affect the industrial output. But government expenditure and foreign aid do not have granger cause on industrial output. It indicates that the intervention of government and foreign sectors in the free working economy hurts the size of the output. The industrial sector government expenditure and foreign aid have not seemed compelling from an increase in output. So, the government should make a favorable private investment environment, utilization of government expenditure, and foreign aid in productive activities in the industrial sector. The policymakers should have to consider whether the foreign loan and grants are acceptable or not.

This study has some limitations. It is only based on the secondary data of 30 years, starting from 1989/90 and ending at the fiscal year 2018/19. It considers only three influencing variables: government expenditure, credit, and foreign aid of industrial sector output. It only shows the condition, co-integration, and causal relationship of the industrial sector output, government expenditure, Credit of CBs, and foreign aid. The relation and causality were identified by using EViews10 and Minitab 19. Therefore, further researches are necessary to be done by utilizing other variables, tools, and software.

\section{References}

Adetiloye, K., Felicia, O.O., \& Taiwo, J.N., (2016). Fraud Prevention and Internal Control in the Nigerian Banking System. International Journal of Economics and Financial Issues. 6. 1172-1179.

Anyeneh, S. E., Ezu, G. K., \& Ananwude, A. C. (2019). Government Expenditure and Industrial Development in Nigeria: Long Run and Short-Run Dynamics from ARDL Approach. Journal of Scientific Research and Reports, 23(6), 1-9. https://doi.org/10.9734/jsrr/2019/v23i630136

Published by:

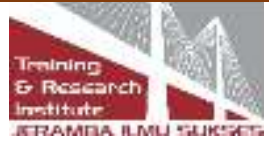


Aryal S.R. Shrestha N.L., Sharma, A., Dhital., R., \&Pradhan M.C. (2014). Development of Manufacturing Industries in Nepal: Current state and future Challenges. Kathmandu: Central Bureau of Statistics, Government of Nepal.

Ehikioya, L., Ehikioya, L., Ismaila \& Mohammed. (2013). Commercial Banks Credit Accessibility and Sectoral Output Performance in a Deregulated financial Market Economy: Empirical Evidence from Nigeria. Journal of Finance and Bank Management; 1(13)

Emmanuel F.o and oladiran O.I (2015). Effect of government Capital Expenditure on Manufacturing sector Output in Nigeria. Business and Economic Research; 5(2).

Falade O.E \& Olagbaju I. (2015). Effect of Government Capital Expenditure on Manufacturing sector Output in Nigeria. Business and economic research, 5(2).136-152.

GoN (2002). Economic Survey of Nepal for 2001/02. Kathmandu: Government of Nepal, Ministry of Finance.

GoN (2009) Economic Surveys of Nepal 2008/09. Kathmandu: Government of Nepal. Ministry of Finance.

GoN (2020). Economic Surveys of Nepal 2019/20. Kathmandu: Government of Nepal. Ministry of Finance.

Hacievliyagil, N. \& Eksi, I. H. (2017). A micro Based Study on Bank Credit and Economic Growth: Manufacturing sub-sector Analysis. Southeast European Journal of Economics and Business 14 (1). 102-109

Iweriebor S. Egharevaba M.I. \& Adegboye A.C (2015). Government Spending and Industrial Development in Nigeria: A Dynamic Investigation. Annals of the University of Petrosian, Economics, 15(1), 179-190.

Jac, H. \& Stephen K (2015). Foreign Aid and Market liberalizing Reform. Washington DC: World Development Bank.

Jha, M. (2016). Waiting for an Industrial revolution. Nepal Times; 23-29 September 2016.

K.C. Niraj (2019). Industrialization is Key to Development. The Kathmandu Post. September 3, 2019.

Lintel, K. B., Selim, Sheikh., Bajracharya, \& Pushkar (2014) Reforms, Incentives, and Banking Sector Productivity: A Case of Nepal, Cardiff Economics Working Papers, No. E2014/14, Cardiff University, Cardiff Business School, Cardiff

Lorember P.T \& Emmanuel J. (2016). Commercial Banks Credit and Manufacturing Sector output in Nigeria. Journal of Economics and Sustainable Development; 7(16), 189-196.

Muchingami, L. Monametsi, G.L, \& Paradza, I. (2017). Bank Lending and Manufacturing Sector growth in Zimbabwe. International Journal of Innovative research in science, engineering, and technology, 6(4). 5119-5125.

Published by:

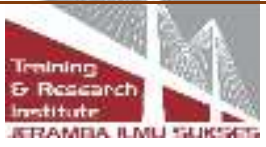

Page 145 
NPC (2019). Fifteenth Economic Plan of Nepal. Kathmandu: National Planning Commission of Nepal.

Ogar, A, Nkamare S.E, \& Effiong C. (2014). Commercial banks credit and its Contribution to the Manufacturing sector in Nigeria. Research Journal of Finance and Accounting; 5(22), Pp. 188-196.

Olokoyo,F.O. Adetiloye, K. A., \& Kieran, O.A., 2016. Bank’s Intermediation Role and Industrial Output in Developing Economies. The Social Sciences, 11: 5838-5844. DOI: $10.36478 /$ sscience.2016.5838.5844

Rahman M, Rahman, S. \& Wu Hai-bing (2011). Time Series Analysis of Causal Relationships among GDP, Agricultural, Industrial, and Service Sector Growth in Bangladesh. ChinaUSA Business Review, 1. 9-15.

Tawose J.O.B (2012). Effects of Bank credit on Industrial Performance in Nigeria. International Journal of Social science; 5(7), Pp. 35-45.

W.B. (2020). Nepal Development Update. Washington DC, World development Bank.

\section{ANNEXURE}

ANNEX 1: Condition of industrial sector output, government expenditure, Credit, and foreign aid

(In a million)

\begin{tabular}{llllll}
\hline $\begin{array}{l}\text { Fiscal } \\
\text { year }\end{array}$ & Loan & $\begin{array}{l}\text { Government } \\
\text { Expenditure }\end{array}$ & Foreign Aid & Gross & Industrial \\
Output & Sector \\
\hline $1989 / 90$ & 3134.7 & 1065.1 & 636.6 & 6455 \\
$1990 / 91$ & 3817.6 & 1766.6 & 1390.9 & 8472 \\
$1991 / 92$ & 4545.6 & 2448.2 & 2174.3 & 13617 \\
$1992 / 93$ & 5389.3 & 1109.6 & 696.9 & 15639 \\
$1993 / 94$ & 6621.1 & 673.5 & 389.9 & 18671 \\
$1994 / 95$ & 11046.9 & 210.4 & 480.3 & 20672 \\
$1995 / 96$ & 15877.6 & 492 & 15.9 & 23808 \\
$1996 / 97$ & 24212.6 & 494.9 & 23.4 & 26311 \\
$1997 / 98$ & 26393.8 & 708.3 & 198.1 & 28540 \\
$1998 / 99$ & 31775.2 & 523.2 & 404.7 & 32033 \\
$1999 / 00$ & 38062.1 & 1065.6 & 298.3 & 35365 \\
$2000 / 01$ & 44885.3 & 550.1 & 29.9 & 37419 \\
$2001 / 02$ & 51008.9 & 820.2 & 368.7 & 34859 \\
$2002 / 03$ & 43309.9 & 790 & 401.2 & 35913
\end{tabular}

Published by: 


\begin{tabular}{lllll}
$2003 / 04$ & 47518.1 & 538.5 & 146.8 & 39194 \\
$2004 / 05$ & 54264.5 & 515.3 & 123.9 & 40305 \\
$2005 / 06$ & 56952.7 & 443.6 & 105.3 & 41246 \\
$2006 / 07$ & 63685 & 590.6 & 116.8 & 42214 \\
$2007 / 08$ & 76824.8 & 653.71 & 78.72 & 42414 \\
$2008 / 09$ & 89581.40 & 640.06 & 80.44 & 42276 \\
$2009 / 10$ & 96733.4 & 167.8 & 0.05 & 42876 \\
$2010 / 11$ & 117391 & 327.86 & 53.31 & 44560 \\
$2011 / 12$ & 1463309 & 416.01 & 40.34 & 46215 \\
$2012 / 13$ & 180149 & 429.82 & 67.65 & 47944 \\
$2013 / 14$ & 210683 & 550.55 & 73.56 & 51047 \\
$2014 / 15$ & 333694 & 783.93 & 129.18 & 51301 \\
$2015 / 16$ & 402886.8 & 688.31 & 225.47 & 47366 \\
$2016 / 17$ & 4858741.6 & 789.04 & 224.96 & 52085 \\
$2017 / 18$ & 5386797.2 & 874.98 & 223.99 & 56849 \\
$2018 / 19$ & 5689621.4 & 1052.65 & 169.64 & 60809 \\
\hline
\end{tabular}

Source: - Economics Surveys of Nepal 2001/02, 2008/09, 2019/20 and CBS

ANNEX II: Lag Selection criteria

VAR Lag Order Selection Criteria

Endogenous variables: LISGO LISGE LISLNC LISFAID

Exogenous variables: C

Sample: 19892018

Included observations: 26

\begin{tabular}{lllllll}
\hline Lag & Log L & LR & FPE & AIC & SC & HQ \\
\hline 0 & -97.87678 & NA & 0.029757 & 7.836676 & 8.030229 & 7.892412 \\
1 & -33.53229 & $103.9411^{*}$ & $0.000736^{*}$ & $4.117868^{*}$ & $5.085635^{*}$ & $4.396550^{*}$ \\
2 & -26.88521 & 8.692331 & 0.001670 & 4.837324 & 6.579304 & 5.338951 \\
3 & -8.030948 & 18.85427 & 0.001766 & 4.617765 & 7.133958 & 5.342338 \\
4 & 8.225422 & 11.25441 & 0.003253 & 4.598044 & 7.888451 & 5.545562 \\
\hline
\end{tabular}

* indicates lag order selected by the criterion

Where L.R.: sequential modified L.R. test statistic (each test at 5\% level)

FPE: Final prediction error

AIC: Akaike information criterion

SC: Schwarz information criterion

H.Q.: Hannan-Quinn information criterion

Published by: 
ANNEX III: Unit Root Test

\begin{tabular}{|c|c|c|c|c|c|c|c|c|c|c|}
\hline \multirow[t]{2}{*}{ Variables } & & \multicolumn{3}{|c|}{ Level } & \multicolumn{3}{|c|}{ First difference } & \multicolumn{3}{|c|}{ Second Difference } \\
\hline & & Intercept & $\begin{array}{l}\text { Trend \& } \\
\text { intercept }\end{array}$ & None & Intercept & $\begin{array}{l}\text { Trend \& } \\
\text { Intercept }\end{array}$ & None & Intercept & $\begin{array}{l}\text { Trend \& } \\
\text { Intercept }\end{array}$ & None \\
\hline \multirow[t]{3}{*}{ LISGO } & t value & -2.9677 & -3.5742 & -1.9533 & -2.9718 & 3.5806 & -1.9533 & -2.9762 & -3.5875 & -1.9538 \\
\hline & ADF test & -7.3304 & -6.034 & 1.3673 & -3.1209 & -3.4716 & -5.257 & -9.2098 & -10.318 & -9.064 \\
\hline & $P$ value & 0.000 & 0.002 & 0.9532 & 0.0364 & 0.6622 & 0.000 & 0.000 & 0.000 & 000 \\
\hline \multirow{3}{*}{ LISGE } & $\mathrm{t}$ value & -2.9677 & -3.5742 & -1.9529 & -2.9718 & -3.5806 & -1.9533 & -2.9762 & -3.5875 & -1.9538 \\
\hline & ADF test & -2.824 & -2.6912 & -0.2122 & -6.6287 & -6.7657 & -6.7470 & -10.489 & -10.3385 & -10.693 \\
\hline & P value & 0.0673 & 0.2471 & 0.6011 & 0.000 & 0.000 & 0.000 & 0.000 & 0.000 & 0,000 \\
\hline \multirow{3}{*}{ LISLNC } & t value & -2.9677 & -3.5742 & -1.9533 & -2.9718 & -3.5806 & -1.9533 & -2.9810 & -3.5950 & -1.9544 \\
\hline & ADF test & -0.4012 & -2.8282 & 2.3465 & -7.2091 & -7.2087 & -6.3135 & -7.1627 & -6.9876 & $-7,3137$ \\
\hline & $P$ value & 0.8963 & 0.1991 & 0.9940 & 0.000 & 0.000 & 0.000 & 0.000 & 0.000 & 0.0000 \\
\hline \multirow{3}{*}{ LISTED } & $\mathrm{t}$ value & -2.9677 & -3.5642 & -1.9533 & -2.9718 & -3.5806 & -1.9533 & -2.9810 & -3.5950 & -1.9544 \\
\hline & ADF test & -3.7866 & -3.9589 & -1.008 & -8.0357 & -7.9580 & -8.177 & -7.0123 & -6.8541 & -7.1640 \\
\hline & $P$ value & 0.007 & 0.0221 & 0.2738 & 0.000 & 0.000 & 000 & 0.000 & 0.000 & 0.000 \\
\hline
\end{tabular}

Source: - Author's calculation by using EViews10

Where $\mathrm{T}$ value $=$ Test critical Value. $\quad$ ADF Value $=$ Augmented Dickey-Fuller Test value

$\mathrm{P}$ Value $=$ Probability Value

LISGO= Industrial sector gross output (taking log)

LISGE= Industrial sector expenditure of government (taking log)

LISLNC $=$ Industrial sector loan of commercial banks (taking log)

LISFAID= Industrial sector foreign aid (taking $\log$ )

Copyrights

Copyright for this article is retained by the author(s), with first publication rights granted to the journal.

It is an open-access article distributed under the terms and conditions of the Creative Commons Attribution license (http://creativecommons.org/licenses/by/4.0/)

Published by: 